\title{
Uji Aktivitas Antibakteri Penyebab Jerawat Staphylococcus epidermidis Menggunakan Ekstrak Daun Ashitaba (Angelica keiskei).
}

\author{
Alvi Kusuma Wardani a, ${ }^{*}$, Yuli Fitriana a, ${ }^{3}$, Sugandi Malfadinata ${ }^{\text {a, }}{ }^{2}$, \\ a,1,2 Dosen Program Studi Farmasi, Fakultas Ilmu Kesehatan Universitas Muhammadiyah Mataram, Mataram, Indonesia \\ a,3 Mahasiswa Program Studi Farmasi, Fakultas Ilmu Kesehatan Universitas Muhammadiyah Mataram, Mataram, Indonesia \\ 1alvikusuma99@gmail.com*; ${ }^{3}$ yulifitriana82@gmail.com \\ *korespondensi penulis
}

\begin{tabular}{|c|c|}
\hline ARTIKEL & \multirow{22}{*}{ 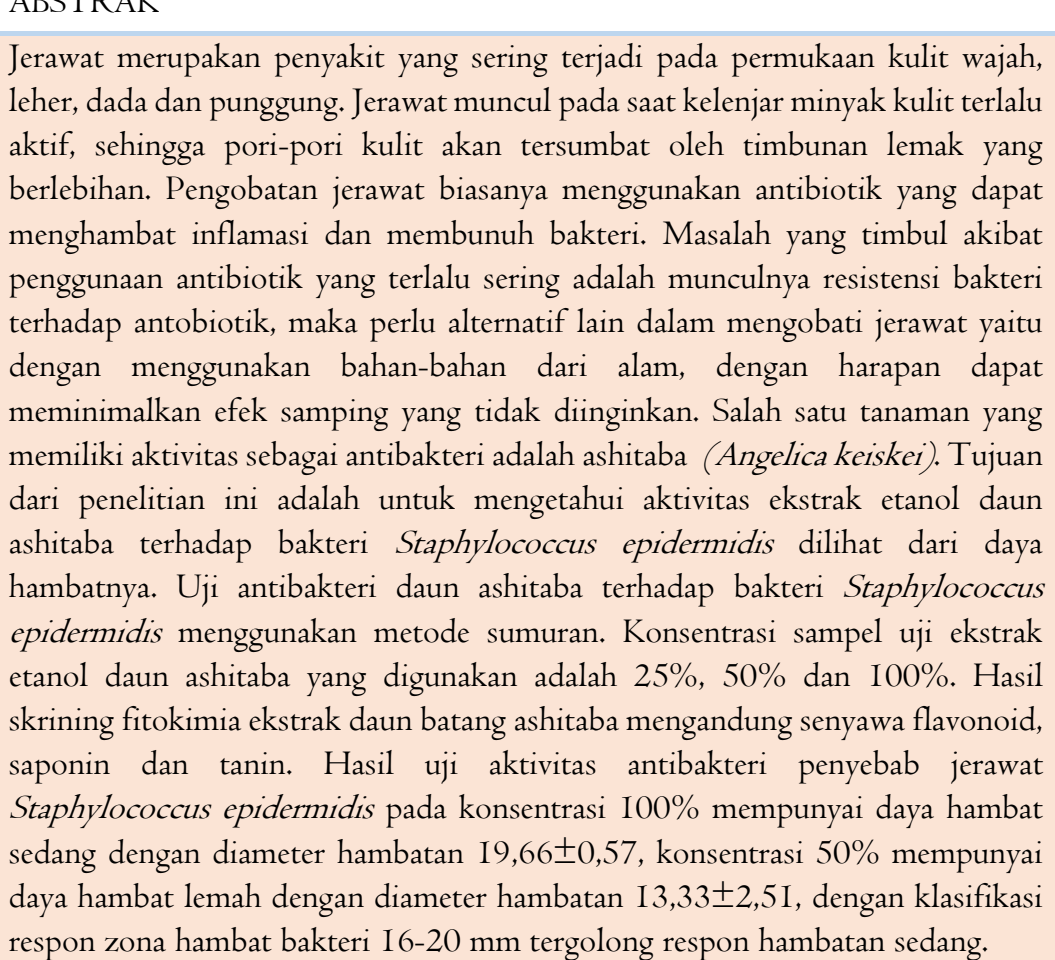 } \\
\hline Dite & \\
\hline 23-12-2019 & \\
\hline Disetujui : & \\
\hline $30-\mathrm{I} 2$ & \\
\hline & \\
\hline Kata kunci: & \\
\hline & \\
\hline & \\
\hline & \\
\hline & \\
\hline & \\
\hline & \\
\hline & \\
\hline & \\
\hline & \\
\hline & \\
\hline & \\
\hline & \\
\hline & \\
\hline & \\
\hline & \\
\hline
\end{tabular}

\section{ABSTRACT}

Keywords :

The leaves of Ashitaba

(Angelica keisker);

Power barrier;

The bacteria

Staphylococcus

epidermidis.
Acne is a disease that often occurs on the surface of the face, neck, chest and back skin. Acne occurs when the skin oil gland is overactive, so the skin pores will be clogged by excessive fat deposits. Treatment of acne usually uses antibiotics that can inhibit inflammation and kill bacteria. Problems arising from the use of antibiotics that are too frequent is the emergence of bacterial resistance to the anthobiotic, it is necessary to alternative in treating acne using ingredients from nature, with the hope of being able to Minimize unwanted side effects. One of the plants that has an antibacterial activity is Ashitaba (Angelica keiskei). The purpose of this study is to find out the activity of Ashitaba-leaf ethanol extract against Staphylococcus epidermidis as seen from the power of his servants. The antibacterial test of the ashitaba leaves against the Staphylococcus epidermidis bacteria uses a Sumuran method. The concentration of the Ashitaba leaf ethanol extract test samples used was $25 \%, 50 \%$ and $100 \%$. The results of phytochemical screening of Ashitaba stem leaf extract contain flavonoid compounds, saponins and tannins. Test results of antibacterial activity of the cause of Staphylococcus epidermidis acne at concentrations of 100\% have moderate resistance with the diameter of the barrier $19,66 \pm 0.57$, the concentration of $50 \%$ has a weak inhibition with a barrier diameter $13,33 \pm$ 
2.5I, with Zone response classification of $16-20 \mathrm{~mm}$ bacteria is classified as a medium barrier response.

\section{PENDAHULUAN}

Jerawat merupakan penyakit yang sering terjadi pada permukaan kulit wajah, leher, dada dan punggung. Jerawat muncul pada saat kelenjar minyak kulit terlalu aktif, sehingga pori-pori kulit akan tersumbat oleh timbunan lemak yang berlebihan (Sawarkar, 2010). Jika timbunan itu bercampur dengan keringat, debu dan kotoran lain, maka akan menyebabkan timbunan lemak dengan bintik hitam di atasnya yang disebut komedo. Jika pada komedo itu terdapat infeksi bakteri, maka terjadilah peradangan yang dikenal dengan jerawat. Peradangan ditimbulkan oleh bakteri Propionibacterium acne, Staphylococcus epidermis, dan Staphylococcus aureus (Wasitaatmaja, I997).

Pengobatan jerawat di klinik kulit biasanya menggunakan antibiotik yang dapat menghambat inflamasi dan membunuh bakteri contohnya tetrasiklin, eritromisin, doksisiklin, dan klindamisin. Selain dari itu sering juga digunakan benzoil peroksid, asam azelat dan ratinoid, namun obat-obat ini memiliki efek samping dalam penggunaannya sebagai anti jerawat antara lain iritasi, sementara menggunakan antibiotik jangka panjang selain dapat menimbulkan resistensi juga dapat menimbulkan kerusakan organ dan imunohipersensitivitas (Djajadisastra, 2009).

Masalah yang timbul akibat penggunaan antibiotik, maka dicari alternative lain dalam mengobati jerawat yaitu dengan menggunakan bahan-bahan dari alam, dengan harapan dapat meminimalkan efek samping yang tidak diinginkan seperti yang terjadi pada pengobatan jerawat dengan antibiotik atau zat-zat aktif lain (Djajadisastra, 2009).

Ashitaba merupakan tanaman suku umbelliferae yang banyak tumbuh pada daerah Sembalun (Lombok Timur). Daunnya banyak dimanfaatkan oleh masyarakat setempat sebagai tanaman pelengkap pangan dan getahnya digunakan untuk mempercepat penyembuhan luka pada tubuh. Beberapa senyawa kalkon yang berhasil diisolasi dari ashitaba antara lain adalah xanthoangelol dan isobavakalkon yang secara lanjut diteliti mempunyai aktivitas sebagai penghambat radikal bebas, antibakteri dan dapat menginduksi apoptosis pada neuroblastoma serta sel leukemia. Selain itu golongan senyawa alkaloid, triterpenoid, saponin, steroid dan glikosida juga terdeteksi pada batang dan daun ashitaba. Sebelumnya telah dilaporkan efek antibakteri dari senyawa kalkon (xanthoangelol dan 4 hydroxyderricin) yang disolasi dari daun ashitaba pada beberapa bakteri Gram positif dan negatif dengan aktifitas paling baik ditunjukkan senyawa pada bakteri Gram positif.

\section{METODE PENELITIAN}

Jenis penelitian ini adalah true eksperimental dengan desain post test only control menggunakan metode sumuran. Penelitian ini dilakukan di Laboratorium Farmakognosi D3 Farmasi Fakultas Ilmu Kesehatan Universitas Muhammadiyah Mataram dan Laboratorium Kesehatan Pengujian Dan Kalibrasi (BLKPK) Kota Mataram. Penelitian ini dilakuan di bulan Juli-Agustus 2019.

I. Alat dan Bahan

Alat Penelitian berupa Cawan petri, Erlenmeyer, timbangan analitik, Bunsen, ose, evaporator, autoklaf, kompor listrik, cotton swab steril, mikropipet, alatalat glas, ayakan dan blender. Bahan penelitian berupa Nutrien agar (NA), MHA, alkohol $70 \%$, alkohol $96 \%$, aquades, larutan garam fisiologis, larutan 0,5 Mc Farland, bakteri Staphylococus aureus, ekstrak daun ashitaba, aquades Steril.

\section{Jalannya Penelitian}

\section{Skrining Fitokimia Ekstrak Daun Ashitaba}

a. Pemeriksaan pendahuluan

Sebagian ekstrak daun ashitaba dimasukkan ke dalam tabung reaksi dengan ditambah aquadest I0 mL lalu dipanaskan selama 30 menit di atas penangas sampai mendidih. Larutan yang terbentuk lalu disaring. Apabila larutan yang diperoleh berwarna kuning-merah, berarti mengandung senyawa yang mempunyai gugus kromofor (flavonoid, tanin, alkaloid, maupun saponin).

b. Uji Kandungan Flavonoid

Ekstrak daun ashitaba diteteskan pada kertas saring kemudian diuapi dengan amoniak. Apabila muncul warna kuning intensif menunjukkan adanya flavonoid.

c. Uji Kandungan Saponin (Uji Busa)

Larutan sampel ditambahkan 2 tetes $\mathrm{HCl}$ I N. Bila terbentuk busa yang stabil \pm 7 menit, maka sampel positif mengandung saponin.

d. Uji Kandungan Tannin

Sampel ditambahkan $\mathrm{I} 0$ tetes larutan $\mathrm{FeCl3}$ I\%. Larutan positif mengandung tanin dan senyawa fenol apabila menghasilkan warna hijau, merah, biru atau hitam pekat.

Cara Kerja Mengukur Daya Hambat

a. Menyiapkan alat dan bahan yang akan digunakan 
b. Menyiapkan suspensi bakteri murni Staphylococcus epidermidis dengan kekeruhan 0,5 unit mac farland.

c. Menyiapkan media Muller Hinton Agar(MHA).

d. kemudian dioleskan suspensi bakteri dengan menggunakan swap kapas steril sehingga merata pada permukaan media.

e. buat sumuran pada media MHA dengan menggunakan blue tip steril dengan cara ditempelkan hingga terbentuk sumuran pada permukaan media.

f. Masukkan filtrat daun ashutaba banyak $50 \mu \mathrm{l}$ pada masing-masing sumuran dengan konsentrasi $25 \%$, 50\%, dan $100 \%$. Kemudian di media lain menggunakan micro pipet masukkan $50 \mu \mathrm{l}$ kontrol positif antibiotik tetrasiklin.

g. Diinkubasi pada suhu $37^{\circ} \mathrm{C}$ selama $24 \mathrm{jam}$.

h. Diukur besarnya zona hambatan pada media. Zona hambat dihitung dengan cara mengukur diameter horizontal dan diameter vertical dari zona hambat yang terbentuk. Kemudian dimasukkan ke dalam rumus untuk mencari ratarata zona hambat kemudian dimasukkan pada tabel kerja. Dengan rumus: ( Eskha dkk., 20I7 )

$$
\mathrm{L}=\frac{(\mathrm{D} 1-\mathrm{D} 2)+(\mathrm{D} 2-\mathrm{D} 2)}{2}
$$

Keterangan

$$
\begin{array}{ll}
\text { L } & \text { : Luas zona hambat } \\
\text { DI } & \text { : Diameter zona hambat horizontal } \\
\text { D2 } & \text { : Diameter zona hambat vertikal } \\
\text { D3 } & \text { : Diameter sumura }
\end{array}
$$

\section{HASIL DAN PEMBAHASAN}

Hasil Skrining Fitokimia

Skrining fitokimia dilakukan untuk mengidentifikasi zat aktif yang belum tampak melalui suatu tes atau pemeriksaan yang dapat dengan cepat memisahkan antara bahan alam yang memilki kandungan fitokimia tertentu. Metode skrining fitokimia dilakukan dengan melihat reaksi pengujian warna dengan menggunakan suatu pereaksi warna (Kristianti dkk, 2008).

Berdasarkan hasil uji kualitatif pada ekstrak daun ashitaba dari tiap-tiap perlakuan diperoleh hasil sebagai berikut :

Sebelum melakukan penelitian dilakukan uji pendahuluan atau uji senyawa yang terkandung dalam daun ashitaba tersebut, meliputi uji flavonoid dan saponin. Hasil uji dapat dilihat pada tabel 4.2.
Tabel 4.2 Hasil uji pendahuluan senyawa atau zat aktif ekstrak daun ashitaba

\begin{tabular}{|c|c|c|c|}
\hline No & $\begin{array}{c}\text { Golongan } \\
\text { senyawa }\end{array}$ & Hasil & Keterangan \\
\hline I & Flavonoid & + & $\begin{array}{c}\text { Muncul warna } \\
\text { kuning } \\
\text { intensif } \\
\text { setelah diuapi } \\
\text { amoniak }\end{array}$ \\
\hline 2 & Saponin & + & $\begin{array}{c}\text { Terbentuk } \\
\text { busa stabil }\end{array}$ \\
\hline 3 & Tanin & + & $\begin{array}{c}\text { Larutan } \\
\text { bewarna hitam } \\
\text { pekat }\end{array}$ \\
\hline
\end{tabular}

Pengujian Uji Aktivitas Antibakteri Penyebab Jerawat Staphylococcus epidermidis Menggunakan Ekstrak Daun Ashitaba

Uji untuk mengetahui penghambatan ekstrak maserasi ekstrak daun ashitaba terhadap pertumbuhan Staphylococcus epidermidis dilakukan dengan tahapan pertama pembuatan konsentrasi ekstrak daun ashitaba, kemudian pembuatan suspensi bakteri dan uji sensitivitas bakteri dengan metode sumuran. Pembuatan larutan induk (konsentrasi I00\%) 3 gram ekstrak daun ashitaba ditambahkan dengan $3 \mathrm{ml}$ aquadest steril kemudian dicampur dan diaduk sampai terlarut kemudian membuat konsentrasi 50\%, 25\%. Pembuatan suspensi bakteri Staphylococcus epidermidis dengan kepekatan 0,5 unit Mc. Farland. Kemudian dioleskan suspensi bakteri menggunakan swap kapas steril hingga merata pada media MHA. Selanjutnya dibuat lubang-lubang sumuran menggunakan blue tip steril sekitar Iml yang ditekan pada media, dengan konsentrasi $25 \%$, $50 \%$, dan $100 \%$, letakkan pada masing-masing sumuran. Disamping itu letakkan paperdisk antibiotik tetrasiklin pada kontrol positif dan dengan mikro pipet, pipetkan $50 \mu \mathrm{L}$ kontrol negatif (Aquadest). Kemudian dilihat adanya zona hambatan dan diukur dengan menggunakan penggaris besar zona hambatnya. Zona hambat dihitung dengan cara mengukur diameter horizontal dan diameter vertikal darizona hambat yang terbentuk.

Uji aktivitas antibakteri penyebab jerawat Staphylococcus epidermidis menggunakan ekstrak daun ashitaba menggunakan metode sumuran dengan menggunakan media Muller Hinton Agar (MHA), dari tiap-tiap media didapatkan adanya pengaruh ekstrak daun ashitaba terhadap pertumbuhan bakteri Staphylococcus epidermidis adapun zona hambat yang terbentuk dapat dilihat pada table 4.4.I. 
Tabel 4.4.I Hasil Uji Aktivitas Penyebab Jerawat Staphylococcus epidermidis Menggunakan Ekstrak Daun Ashitaba dengan Menggunakan Metode Sumuran

\begin{tabular}{|c|c|c|c|c|c|}
\hline \multirow{2}{*}{$\begin{array}{l}\text { Replik } \\
\text { asi }\end{array}$} & \multicolumn{3}{|c|}{ Konsentrasi } & \multicolumn{2}{|c|}{ Kontrol } \\
\hline & I00\% & $50 \%$ & $25 \%$ & $\begin{array}{l}\text { Tetra } \\
\text { siklin } \\
(+)\end{array}$ & $\begin{array}{l}\mathrm{Aq} \\
\text { uad } \\
\text { es } \\
(-)\end{array}$ \\
\hline I & $\begin{array}{l}20 \\
\mathrm{~mm}\end{array}$ & $\begin{array}{l}\mathrm{I} 6 \\
\mathrm{~mm}\end{array}$ & $\begin{array}{l}0 \\
\mathrm{~mm}\end{array}$ & \multirow[t]{3}{*}{$\begin{array}{l}2 \mathrm{I} \\
\mathrm{mm}\end{array}$} & \multirow[t]{3}{*}{$\begin{array}{l}\mathrm{O} \\
\mathrm{mm}\end{array}$} \\
\hline 2 & $\begin{array}{l}\text { I9 } \\
\mathrm{mm}\end{array}$ & $\begin{array}{l}\text { II } \\
\mathrm{mm}\end{array}$ & $\begin{array}{l}0 \\
\mathrm{~mm}\end{array}$ & & \\
\hline 3 & $\begin{array}{l}20 \\
\mathrm{~mm}\end{array}$ & $\begin{array}{l}\mathrm{I} 3 \\
\mathrm{~mm}\end{array}$ & $\begin{array}{l}\mathrm{O} \\
\mathrm{mm}\end{array}$ & & \\
\hline $\begin{array}{l}\text { Mean } \\
\pm \text { SD }\end{array}$ & $\begin{array}{l}19,66 \\
\pm 0,5 \\
7\end{array}$ & $\begin{array}{l}\mathrm{I} 3,3 \\
3 \pm 2, \\
5 \mathrm{I}\end{array}$ & $\begin{array}{l}0,00 \\
\pm 0,0 \\
0\end{array}$ & $\begin{array}{l}2 \mathrm{I}, 00 \\
\pm 0,0 \\
0\end{array}$ & $\begin{array}{l}0,0 \\
0 \pm \\
0,0 \\
0\end{array}$ \\
\hline $\begin{array}{l}\text { Interpr } \\
\text { estasi }\end{array}$ & $\begin{array}{l}\text { Sedan } \\
\mathrm{g}\end{array}$ & $\begin{array}{l}\text { Lem } \\
\text { ah }\end{array}$ & $\begin{array}{l}\text { Tida } \\
\mathrm{k} \text { ada }\end{array}$ & Kuat & $\begin{array}{l}\text { Tid } \\
\text { ak } \\
\text { ada }\end{array}$ \\
\hline
\end{tabular}

Hasil penelitian ini menunjukkan bahwa adanya daya hambat ekstrak daun ashitaba terhadap bakteri Staphylococcus epidermidis. Daya hambat ditunjukkan dengan adanya zona bening yang terbentuk di sekitar sumur yang diisi dengan ekstrak daun ashitaba. Zona bening tersebut berwarna agak kehitaman yang dihasilkan oleh warna ekstrak daun ashitaba. Hal yang sama juga dapat dilihat pada daerah sumuran yang diisi tetrasiklin sedangkan pada daerah sumuran yang diisi aquadest steril tidak terlihat adanya zona bening yang terbentuk.

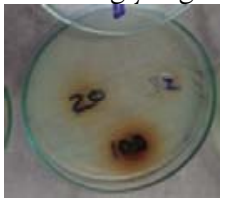

Gambar 4.4.I Zona Bening Ekstrak Daun Ashitaba (Dokumentasi Peribadi)

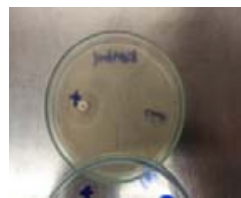

Gambar 4.4.2 Zona Bening Kontrol Positif dan Negatif (Dokumentasi Peribadi)

Penentuan aktivitas daya hambat antimikroba mengacu pada tabelkategori kekuatan aktivitas antibakteri. Data hasil pengukuran diameter zona hambat dibandingkan dengan Tabe 4.4.2
Tabel 4.4.2 Klasifikasi Respon Zona Hambat Bakteri (Greenwood, I995)

\begin{tabular}{|l|l|}
\hline $\begin{array}{l}\text { Diameter zona } \\
\text { hambat }\end{array}$ & $\begin{array}{l}\text { Respon hambatan } \\
\text { pertumbuhan }\end{array}$ \\
\hline$>20 \mathrm{~mm}$ & Kuat \\
\hline $16-20 \mathrm{~mm}$ & Sedang \\
\hline$<15 \mathrm{~mm}$ & Lemah \\
\hline
\end{tabular}

Percobaan dilakukan sebanyak $3 \mathrm{x}$ replikasi agar dapat membandingkan zona hambat yang terbentuk. Rata-rata zona hambat yang terbentuk pada kontrol positif tetrasiklin adalah $2 \mathrm{I} \mathrm{mm}$, sedangkan pada ekstrak daun ashitaba dengan konsentrasi I00\% b/v; $20 \mathrm{~mm}$, pada konsentrasi $50 \% \mathrm{~b} / \mathrm{v} ; 16 \mathrm{~mm}$, pada konsentrasi $25 \% \mathrm{~b} / \mathrm{v} ; 0 \mathrm{~mm}$. Kontrol negatif memperlihatkan bahwa tidak adanya zona bening di sekitar area sumuran yang sudah di tumbuhi bakteri, yang artinya tidak adanya aktifitas antibakteri kontrol negatif terhadap pertumbuhan bakteri Staphylococcus epidermidis. Pada kontrol positif memperlihatkan bahwa adanya zona bening yang terjadi disekitar ares disk yang sudah ditumbuhi bakteri, dengan diameter zona hambat yang terbentuk adalah $21 \mathrm{~mm}$. Pada konsentrasi $25 \%$ tidak ada terbentuk zona hambat disekitar area sumuran. Pada konsentrasi 50\% memperlihatkan bahwa disekitar area sumuran terbentuk zona hambat, dimana zona hambat yang terbentuk adalah $16 \mathrm{~mm}$, lebih besar dibandingkan dengan konsentrasi $25 \%$. Pada konsentrasi I00\% memperlihatkan bahwa disekitar area sumuran terbentuk zona hambat, dimana zona hambat yang terbentuk adalah $20 \mathrm{~mm}$, lebih besar dibandingkan dengan konsentrasi $50 \%$ akan tetapi tidak melebihi zona hambat yang terbentuk pada kontrol positif tetrasiklin dengan zona hambat 2I mm dan tidak sama dengan zona hambat pada kontrol negatif aqudes steril dengan tidak adanya terbentuk zona hambat $(0 \mathrm{~mm})$.

Adanya penghambatan terhadap perkembangan bakteri Staphylococcus epidermidis disebabkan adanya aktifitas senyawa flavonoid dalam ekstrak daun ashitaba yang dapat menghambat bakteri Staphylococcus epidermidis. Hal ini disebabkan karena mekanisme kerja flavonoid dalam menghambat fungsi membran sel dengan membentuk senyawa kompleks dari protein ekstraseluler dan terlarut sehingga merusak membran sel bakteri dan diikuti dengan keluarnya senyawa intraseluler (Masduki, 2003). Flavonoid juga mempunyai efek antibakteri dengan cara merusak membran dan struktur selnya (Ayoola, 2008). Sedangkan kerja flavonoid dalam menghambat metabolisme energi 
adalah dengan menghambat penggunaan oksigen oleh bakteri.

Dari penelitian ini diketahui juga bahwa terdapat perbedaan luas zona hambat yang terbentuk hal ini terlihat dari adanya variasi zona pada masingmasing bahan coba. Perbedaan ini dapat disebabkan oleh beberapa faktor, antara lain besarnya inokulum, waktu inkubasi, konsentrasi ekstrak, dan daya antibakteri zat berkhasiat. Makin besar inokulum maka semakin kecil daya hambatnya, sehingga semakin kecil zona yang terbentuk. Konsentrasi ekstrak memengaruhi kecepatan difusi zat berkhasiat. Makin besar konsentrasi ekstrak, maka makin cepat difusi, akibatnya makin besar daya antibakteri dan makin luas diameter zona hambat yang terbentuk hal ini sesuai dengan hasil penelitian bahwa ekstrak dengan konsentrasi I00\%mempunyai zona hambat yang lebih besar dibandingkan dengan konsentrasi 25\%, dan 50\%. (Kumala, Indriani, 2008).

Kontrol negatif memperlihatkan bahwa tidak terdapat zona bening atau daya hambat disekitar area sumuran yang ditumbuhi bakteri, itu berarti tidak adanya aktifitas antibakteri terhadap penghambatan pertumbuhan bakteri Staphylococcus epidermidis, hal ini terjadi karena aquadest adalah air dari hasil penyulingan yang kandungannya murni $\mathrm{H}_{2} \mathrm{O}$, sehingga tidak memiliki aktifitas terhadap bakteri.

Kontrol positif memperlihatkan bahwa disekitar area disk terbentuk zona bening, yang berarti ada aktifitas antibakteri terhadap penghambatan pertumbuhan bakteri Staphylococcus epidermidis, sebagai kontrol positif digunakan tetrasiklin yang memiliki daya hambat 2I mm yang dapat dikatakan tingkat kuat karena melebihi ketentuan dari nilai kuat $(>20 \mathrm{~mm})$.

Tetrasiklin termasuk kedalam golongan antibiotik aminiglikosida dengan cara kerjanya adalah menghambat atau menginhibisi sintetis protein pada bakteri dengan cara mengganggu fungsi subunit $30 S$ ribosom, dan merupakan antibiotik yang mampu menghambat bakteri gram positif maupun gram negatif. Golongan Staphylococcus memiliki enzim betalaktamase yang dapat memecah cincin betalaktm dan membuatnya menjadi tidak aktif (Junaidin dan Admin, 200).

\section{SIMPULAN}

Berdasarkan hasil penelitian uji aktivitas antibakteri penyebab jerawat Staphylococcus epidermidis menggunakan ekstrak daun ashitaba dapat disimpulkan bahwa ekstrak daun ashitaba memiliki efek sebagai antibakteri dalam menghambat partumbuhan bakteri Staphylococcus epidermidis dan tergolong memiliki respon zona hambat yang sedang, dan luas zona hambat yang didapatkan pada

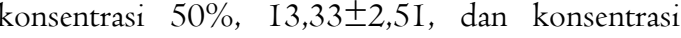
I00\%, I9,66士0,57 dapat disimpulkan bahwa semakin tinnggi konsentrasi ekstrak, maka zona hambat yang dihasilkan semakin besar.

\section{UCAPAN TERIMA KASIH}

Saya ucapkan terimakasih kepada dosen pembimbing I dan 2 serta penguji yang telah membantu saya menyelsaikan penelitian ini.

\section{REFERENSI}

Akiyama, H., Fujii., Yamasaki, O., Oono, T., Iwatsuki, T. (200I). Antibacterial Action of Several Tannins Agains Staphylococcus epidermidis. Journal of Antimicrobial Cemoterapy

Azzamy, 2015. Ashitaba, Seledri Jepang Kaya Manfaat. (Online) Available at: http://mitalom.com/ashitaba-seledrijepang-kaya-manfaat/ (Diakses 9 april 2017).

Departemen Kesehatan Republik Indonesia. (2000). Parameter standar umum ekstrak tumbuhan obat (Cetakan I). Jakarta: Direktorat Jendral Pengawasan Obat dan Makanan.

Dewi, S.A., 2009, Cara Ampuh Mengobati Jerawat, Buana Pustaka, Jakarta.

Djajadisastra, Joshita, et al., 2009. Formulasi Gel Topikal Dari Ekstrak Nerii Folium Dalam Sedian Anti Jerawat. Jurnal Farmasi Indonesia Vol. 4 No 4

Jawetz, E., Melnick, J. L., \& Adelberg, E. A., 2005, Mikrobiologi Kedokteran, edisi XXII, diterjemahkan oleh Bagian Mikrobiologi Fakultas Kedokteran Universitas Airlangga, 205, 235, Penerbit Salemba Medika, Jakarta

Miksusanti., Betty sri laksmi,J.,Rizal syarief, Bambang pontjo, Gatot trimulyadi., 2009., Antibacterial Activity Of Temu Kunci Tuber (Kaempheria pandurata) Essential Oil Against Bacillus cereus, Med J Indones, vol I8 No I : I I

Nishimura R, Tabata K, Arakawa M, Ito Y, Kimura $\mathrm{Y}$, Akihisa $\mathrm{T}$, et al. Isobavachalcone, a chalcone constituent of Angelica keiskei, induces apoptosis in neuroblastoma. Biological and Pharmaceutical Bulletin. 2007;30(I0):I878-I883.

Pratiwi, Silvya T. 2008. Mikrobiologi Farmasi. Jakarta: Erlangga

Radji, M., 20II, Buku Ajar Mikrobiologi Panduan Mahasiswa Farmasi dan Kedokteran, I07, II8, 20I-207, 295, Jakarta, Buku Kedokteran EGC. 
Salle, A. J., I96I, Fundamental Principles of Bacteriology,5th Edition, 719, 738, New York, Mc. Graw Hill Company Inc.

Sawarkar, H.A., Khadabadi, S.S., Mankar, D.M., Farooqui, I.A., Jagtap, N.S., 2010., Development and Biological Evaluation Of Herbal AntiAcne Gel., vol.2, no.3, pp 2028-203I., International Journal Of PharmTech Research

Sembiring, B. B., \& Manoi, F. (20II). Identifikasi Mutu Tanaman Ashitaba. Buletin Penelitian Tanaman Rempah Dan Obat, 22(2).

Suhartati, R. \& Nurasih, I., 2016. Aktivitas Antibakteri Ekastrak Air Daun Ashitaba (Angelica kesker) terhadap Bakteri Pseudomonas aeruginosa secara In Vitro, Jurnal Kesehatan Bakti Tunas Husada, I6(I):II3-II8.

Tiwari, P. Kumar, B. Kaur, M. Kaur, G. Kaur, H. 20II. Phytochemical screening and Extraction: A review. International Pharmaceutical Sciencia. Vol. I. Issue. I.

Wasitaatmadja, SM. I997. Penuntun IlmuKosmetik Medik. Jakarta: Penerbit U Press. 